\title{
Fundamental Analysis of Stock Returns of Non-financial Firms Listed at the Nairobi Securities Exchange
}

\author{
Ogilo Fredrick, ${ }^{1, *}$, Benard Nthenge Muiva ${ }^{2}$ \\ ${ }^{1}$ School of Business, University of Nairobi, Mombasa Campus, Kenya \\ ${ }^{2}$ University of Nairobi, Mombasa Campus, Kenya
}

Copyright ( $(2015$ by authors, all rights reserved. Authors agree that this article remains permanently open access under the terms of the Creative Commons Attribution License 4.0 International License

\begin{abstract}
The study sought to examine the relevance of firm fundamentals in explaining stock returns of non-financial firms listed at the Nairobi Securities Exchange. The study employed a descriptive research design. A census targeting the 44 non-financial firms listed between the years 2004 and 2013 was conducted. The study used secondary data obtained from Nairobi Securities Exchange. The relationship between stock returns and three fundamentals was measured using the Karl Pearson moment correlation coefficient while regression analysis was used to determine the effect of change in total assets, change in revenue and change in financial leverage on stock returns. The overall significance of the model was tested using $F$ test while the significance of the individual independent variable was tested using t-test. The study found a weak positive correlation between stock returns and change in total assets, while change in revenue and change in financial leverage exhibited a negative relationship with stock returns. However, the relationship between stock returns, change in total assets, change in revenue and change in financial leverage was found not to be significant. The study concluded that change in total assets, change in revenue and change in financial leverage cannot be used to meaningfully estimate stock returns for non-financial firms listed at the Nairobi Securities Exchange. Further studies may explore the fundamental factors that significantly influences stock returns at the Nairobi Securities Exchange by further analyzing the information reported in financial statements.
\end{abstract}

Keywords Fundamental Analysis, Non-financial Firms, Stock Returns, Fundamental Factors

\section{Introduction}

Fundamental analysis is the examination of the underlying forces that affect the well-being of the economy, industry groups and companies. At the company level, fundamental analysis involves examination of financial data, management, business concept and competition. It is a method of analyzing a company's stock prices using historical accounting and financial data. In addition to understanding the business, fundamental analysis allows investors to develop an understanding of the key value drivers within the company as stock's price are heavily influenced by firm fundamentals (Bauman, [1]). Pinto, Henry, Robinson and Stowe [2] define fundamentals as characteristics of a company related to its assets, profitability, financial strength, risk or growth. They argue that market prices reflect the market assumptions and expectations on the company underlying fundamentals. Fundamentals drive cash flows and the market value securities as the present value of the future cash flows discounted at the appropriate required rate of return.

Fama [3] asserted that the stock market movements are driven by news about firm economic fundamentals. Accordingly the price of a stock at any point in time reflects the market unbiased assessment of the net present value of all future cash flows, discounted at a rate commensurate with the riskiness of those cash flows. The efficient market hypothesis suggests that developed capital markets incorporate into the stock price all available public and private information about present and past operational performance of the firm. An important body of research in the last two decades and recent and growing research in emerging markets suggest that the efficient market hypothesis does not always consistently hold (Aggarwal and Gupta, [4]). Xie [5] asserts that the more developed a capital market, the closer to market efficiency it is, and in emerging markets it is likely that prices do not efficiently incorporate all available information into stock prices in a timely and accurate manner.

Investment research seeks to identify what factors explain stock price movements so that investors trading on such information can generate abnormal returns. In light of the increasing value of equities at the Nairobi Securities Exchange and the growing investors' interest from both local and foreign investors, retail as well as institutional, analysis of pertinent financial information play a crucial role in 
identifying profitable investments. An item on the financial statement is considered as value relevant if it is significantly correlated with equity returns (Bruce, [6]). Fundamental analysis is a useful technique to identifying value relevant signals which investors can profitably exploit especially when markets are not fully efficient. Odumbe [7] found out that the NSE exhibit weak form efficiency and only reacts to new information in a lagged manner. Therefore it can be expected that some scope exhibit for gainfully using fundamental analysis at the NSE. The challenge would then be identifying fundamental signals that are value relevant.

\section{Fundamental Drivers of Stock Returns}

Firm fundamentals refer to characteristics of a company related to its assets, profitability, financial strength, risk or growth. Security market prices reflect the market assumptions and expectations on the company underlying fundamentals. Fundamentals drive cash flows and the market value securities as the present value of the future cash flows discounted at the appropriate required rate of return (Pinto et $\mathrm{al}$, [8]). This study considered three firm fundamental drivers of returns namely revenue growth, assets growth and change in leverage.

Revenue is typically the single largest item reported in a company's financial statements. As with all the important bottom line and cash flows, companies' reported revenues are not only significant to these companies' financial statements in money terms, but also in the weight and importance that investors place on them in making investment decisions. Trends and growth in the top line of a company's income statement are barometers investors use to assess the company's past performance and future prospects (Aghion and Stein, [9]).

Graham, Harvey and Rajgopal [10] found out that executives consider revenue growth as one of the three most important performance measures for external constituents. Kaplan and Norton [11] argued that firms must use a wide variety of goals, including sales growth, to effectively reach their financial objectives.

Asset growth is form of investment in which the company management adds value to shareholders wealth. This investment strategy is emerging to be the normative idea for many firms. It is common for the management of a company to expect that an asset bought now as an investment will perform better in the future resulting to higher shareholders return. However, the management has to assess the derivative impact of investing heavily on assets in relation to stock returns (Chen and Zhang, [12]). Asset growth illustrates how changes in company's assets will affect the returns of the companies, which believe that change of percentage in total assets is a better indicator in measuring the growth of the company (Piotroski, [13]). The use of asset growth is motivated by the findings of Cooper, Gulen, and Schill [14] who found out that asset growth at the firm-level is a strong and robust negative predictor of cross-sectional variation in stock returns.

Leverage refers to the proportion of debt to equity in the capital structure of a firm. The financing or leverage decision is a significant managerial decision because it influences the shareholder's return and risk and the market value of the firm. The ratio of debt-equity has implications for the shareholders' dividends and risk, this affect the cost of capital and the market value of the firm (Pandey, [16]). According to the theory by Myers and Majiluf [15] the capital structure of companies always stays at optimal level. Change in leverage occurs when firms need more money due to various reasons, for example financing new projects, maintaining liquidity position or repaying loans etc. The change in leverage serves a signal to investors who will make investing decision with regards to this information. Therefore, the change in leverage is value relevant because it will affect the decision of investors (Dimitrov and Jain, [17]).

\section{Objectives}

This study sought to examine the relevance of a set of fundamental signals in driving stock returns of non-financial firms listed at the NSE. The specific objectives were;

i. To determine the relationship between stock returns and change in total asset, change in revenue growth and change in leverage.

ii. To determine effect of change in total assets, change in revenue and change in leverage on stock returns at the Nairobi Securities Exchange.

\section{Methods}

A descriptive research design was used in this study. The study targeted 44 non-financial companies listed at the Nairobi Securities Exchange as at December 31, 2013. Firms in the financial sector were excluded because of the differing reporting requirements in the sector and the regulations that do not apply to the non-financial companies. A census study was conducted. This research study made use of secondary data. For each company end of year stock price, number of shares outstanding, revenue, total assets and total debt at the end of each year was recorded. Stock returns were regressed against change in revenue, change in total assets and changes in leverage as the independent variables. The significance of each explanatory variable were tested using student $\mathrm{t}$ - test while an F- test for the significance of the regression model was conducted. Coefficient of determination R2 was used to interpret the explanatory power of the regression model. The following analytical model based on three firm fundamentals namely change in aggregate firm revenue, change in aggregate assets and change in financial leverage was used.

$$
\mathrm{R}_{\mathrm{i}, \mathrm{t}}=\alpha+\beta_{1} \Delta \mathrm{AGGREV}+\beta_{2} \Delta \mathrm{AGGTA}+\beta_{3} \Delta \mathrm{FLEV}+\varepsilon_{\mathrm{i}}
$$

Where $\mathrm{R}_{\mathrm{i}, \mathrm{t}}=$ Return of stock $\mathrm{i}$ in period $\mathrm{t}$ 
$\triangle \mathrm{AGGTA}=\mathrm{Change}$ in aggregate total assets

$\triangle \mathrm{FLEV}=\mathrm{Change}$ in financial leverage $\varepsilon_{\mathrm{i}}=$ Residual term

\section{Results and Discussions}

Table 1. Correlation matrix

\begin{tabular}{|c|c|c|c|c|c|}
\hline & & Return & $\begin{array}{c}\text { Change } \\
\text { TA }\end{array}$ & $\begin{array}{c}\text { Change } \\
\text { REV }\end{array}$ & $\begin{array}{c}\text { Change } \\
\text { LEV }\end{array}$ \\
\hline \multirow{2}{*}{ Return } & $\begin{array}{c}\text { Pearson } \\
\text { Correlation }\end{array}$ & 1 & .010 & -.045 & -.010 \\
\hline & $\begin{array}{c}\text { Sig. } \\
\text { (2-tailed) }\end{array}$ & & .874 & .453 & .866 \\
\hline \multirow{2}{*}{$\begin{array}{c}\text { Change } \\
\text { TA }\end{array}$} & $\begin{array}{c}\text { Pearson } \\
\text { Correlation }\end{array}$ & .010 & 1 & $.237^{* *}$ & .028 \\
\hline & $\begin{array}{c}\text { Sig. } \\
\text { (2-tailed) }\end{array}$ & .874 & & .000 & .635 \\
\hline \multirow{2}{*}{$\begin{array}{c}\text { Change } \\
\text { REV }\end{array}$} & $\begin{array}{c}\text { Pearson } \\
\text { Correlation }\end{array}$ & -.045 & $.237^{* *}$ & 1 & .023 \\
\hline & $\begin{array}{c}\text { Sig. } \\
\text { (2-tailed) }\end{array}$ & .453 & .000 & & .704 \\
\hline \multirow{2}{*}{$\begin{array}{c}\text { Change } \\
\text { LEV }\end{array}$} & $\begin{array}{c}\text { Pearson } \\
\text { Correlation }\end{array}$ & -.010 & .028 & .023 & 1 \\
\hline & $\begin{array}{c}\text { Sig. } \\
\text { (2-tailed) }\end{array}$ & .866 & .635 & .704 & \\
\hline
\end{tabular}

**. Correlation is significant at the 0.05 level (2-tailed).

a. List wise $\mathrm{N}=280$

Stock returns exhibited a positive correlation of 0.01 with change in total assets and a negative correlation with change in revenue and change in leverage of -0.045 and -0.01 respectively. The correlation between stock returns and asset growth is not significant at $5 \%$ level.

Table 2. Model Summary

\begin{tabular}{|c|c|c|c|c|}
\hline Model & $\mathrm{R}$ & R Square & $\begin{array}{c}\text { Adjusted } \\
\text { R Square }\end{array}$ & $\begin{array}{c}\text { Std. Error of the } \\
\text { Estimate }\end{array}$ \\
\hline 1 & $.051^{\mathrm{a}}$ & .003 & -.008 & .55561 \\
\hline
\end{tabular}

a. Predictors: (Constant), Change LEV, Change REV, Change TA

Table 2 provides a summary of the result of regression. The coefficient of determination- $\mathrm{R}$ square for the model is 0.003 . This indicates that change in total assets, change in revenue and change in leverage jointly explain only $0.3 \%$ of the variation in stock returns. This provides a very low predictive/ explanatory power.

Table 3. Analysis of Variance

\begin{tabular}{|c|c|c|c|c|c|c|}
\hline \multicolumn{2}{|c|}{ Model } & $\begin{array}{c}\text { Sum of } \\
\text { Squares }\end{array}$ & df & $\begin{array}{c}\text { Mean } \\
\text { Square }\end{array}$ & F & Sig. \\
\hline \multirow{3}{*}{1} & Regression & .217 & 3 & .072 & .233 & $.873^{\mathrm{a}}$ \\
\cline { 2 - 8 } & Residual & 85.140 & 275 & .310 & & \\
\cline { 2 - 8 } & Total & 85.357 & 278 & & & \\
\hline
\end{tabular}

a. Predictors: (Constant), Change LEV, Change REV, Change TA

b. Dependent Variable: Return

From table 3 the F-statistic for the model is 0.233 with a significance level of 0.873 . The model is not statistically significant at the $5 \%$ level of significance.

Table 4. Regression Coefficients

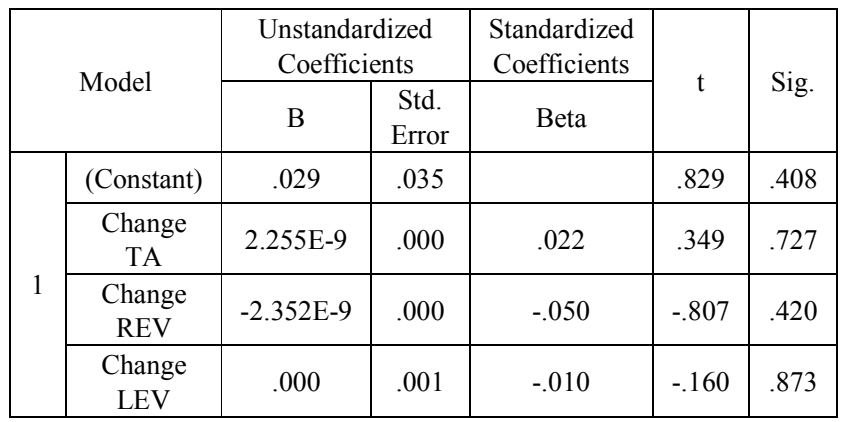

a. Dependent Variable: Return

Table 4 indicates the coefficients of the independent variables for the regression model. Change in total assets has a coefficient of 0.00000000226 while change in revenue has a coefficient of -0.000000002352 and change in leverage has a coefficient of 0.00 . Using these coefficients the regression model is as follows:

$$
\begin{gathered}
\mathrm{R}_{\mathrm{i}, \mathrm{t}}=0.029+0.00000000226 \Delta \text { AGGTA } \\
-0.000000002352 \Delta \text { AGGREV }+0.00 \Delta \mathrm{FLEV} .
\end{gathered}
$$

\section{Conclusions}

It was found out that there exists a positive correlation of 0.01 between stock returns and change in total assets. The value of the correlation of 0.874 in table 1 was found not to be significant at $5 \%$ level. Stock returns exhibited a negative correlation with change in revenue and change in leverage. The correlation coefficient between stock returns and change in revenue was found to be 0.045 as reported in table 1 . This indicated a low level of association between stock returns and change in revenue. The correlation was established not to be statistically significant at 5\% level since it had a value of 0.453. Also stock returns exhibited a low level of association with change in leverage with a correlation coefficient of -0.01 as reported in table 1 , which is not significant at the $5 \%$ level. The level of significance for change in leverage was established to be 0.866 and therefore not significant at 5\% level. The coefficient of change in total assets in table 4 was not significant at 5\% level therefore; changes in total assets have no significant effect on stock returns.

The study also sought to determine the effect of change in total assets, change in revenue and change in financial leverage on stock returns. The coefficient of determination $\mathrm{R}^{2}$ indicated that the three variables did not significantly explain variation in stock returns. The F-test on the regression model for the effect of change in total assets, change in revenue and change in leverage is not statistically significant at $5 \%$ level. The t-test on the significance change in total assets, change in revenue and change on leverage indicated that the three independent variables are not statistically significant at the $5 \%$ level. In overall the 
regression model has poor predictive power and is not statistically significant. Change in total assets, change in revenue and change in leverage cannot be used to meaningfully estimate stock returns.

\section{Implication on Policy and Practice}

Investors may not rely on the variables; Change in total assets; change in revenue and change in leverage in selecting and evaluating the performance of their investments at the Nairobi Securities Exchange since the relationships are not statistically significant. Further studies may seek to identify what fundamental factors are relevant in explaining stock returns. This should focus on the various components of the financial statements. For instance, a decomposition of the firms change in total assets so as to analyze the effect of change in current assets and change in noncurrent assets separately may help reveal whether such changes have a significant effect on stock returns. Further studies may also focus on the change in individual items of current and noncurrent assets, change in current liabilities, and change in long term liabilities.

\section{REFERENCES}

[1] Bauman, M.P. (1996). A Review of fundamental analysis research in accounting. Journal of Accounting Literature, 15, $1-33$.

[2] Pinto, J., Henry, E., Robinson, T. and Stowe, J. (2013). Equity Valuation $2^{\text {nd }}$ edition. John Wiley and sons.

[3] Fama, E. (1970). Efficient capital markets: A review of theory and empirical work. Journal of Finance, 25, 383423.

[4] Aggarwal, N. \& Gupta, M. (2009). Do high book-to-market stocks offer returns to fundamental analysis in India? American Economic Review, 92, 184-190.
[5] Xie, H. (2001). The mispricing of abnormal accruals. The Accounting Review, 76(3), 357-373.

[6] Bruce, L.B. (2001). Qualitative research methods for the social sciences. $4^{\text {th }}$ edition. Boston, Pearson.

[7] Odumbe, K.O. (2010). An empirical investigation of the information content of bonus shares announcement for companies quoted at the Nairobi stock exchange. Unpublished MBA project. University of Nairobi, Kenya.

[8] Pinto, J., Henry, E., Robinson, T. and Stowe, J. (2013). Equity Valuation $2^{\text {nd }}$ edition. John Wiley and sons.

[9] Aghion, P., \& Stein, J. (2008). Growth vs. Margins: Destabilizing consequences of giving the stock market what it wants. Journal of Finance, 63, 1025-1058.

[10] Graham, J. R., Harvey, C. R. \& Rajgopal, S. (2005). The economic implications of corporate financial reporting. Journal of Accounting and Economics, 40, 3-73.

[11] Kaplan, R.S. \& Norton, D.P. (1992). The balanced scorecard. Harvard Business Review, 70(1), 71-79.

[12] Chen, L. \& Zhang, L. (2010). A better three-factor model that explains more anomalies. The Journal of Finance, 65(2), 563-595.

[13] Piotroski, J., (2000). Value investing: the use of historical financial statement information to separate winners from losers. Journal of Accounting Research, 38, 1-42.

[14] Cooper, M., H. Gulen, \& M. Schill. (2008). Asset growth and the cross-section of stock returns. The Journal of Finance, 63(4), 1609-1651.

[15] Myers, S.C. \& Majluf, N. (1984). Corporate financing and investment decisions when firms have information investors do not have. Journal of Financial Economics, 13, 187-221.

[16] Pandey, I. M. (2011). Financial Management. $10^{\text {th }}$ edition. New Delhi: Vikas Publishing House

[17] Dimitrov, V. \& Jain, P. C. (2008). The value-relevance of changes in financial leverage beyond growth in assets and GAAP earnings. Journal of Accounting, Auditing \& Finance, 23(2), 191-222. 